\title{
Variations in the Pattern of Formation of the Abdominis Rectus Muscle Sheath among Kenyans
}

\author{
Variaciones en el Patrón de Formación de la Vaina del Músculo Recto Abdominal en Kenianos
}

\author{
"Mwachaka, P.; **Odula, P.; ****Awori, K. \& ${ }^{* * * *}$ Kaisha, W.
}

MWACHAKA, P.; ODULA, P.; AWORI, K. \& KAISHA, W. Variations in the pattern of formation of the abdominis rectus muscle sheath among Kenyans. Int. J. Morphol., 27(4):1025-1029, 2009.

SUMMARY: The pattern of formation of the human rectus sheath exhibits variations, it is not clear if these variations are population specific. This study aimed at describing the pattern of formation of the rectus sheath in a select Kenyan population. Formation of the rectus sheath was analyzed in eighty subjects ( 47 male, 33 female) during autopsies and cadaveric dissection. The anterior wall of the rectus sheath in all cases was aponeurotic and firmly attached to rectus abdominis muscle. The posterior wall of the rectus sheath was aponeurotic in $71(88.5 \%)$ cases, the rest were musculoaponeurotic and only seen in males. In all cases the aponeurosis of internal oblique abdominis split into two lamina; a deep lamina that fused with the aponeurosis of transverses abdominis at the lateral border of rectus abdominis and a superficial lamina that fused with aponeurosis of external oblique abdominis mid-way between the medial and lateral borders of rectus abdominis muscle. The pattern of formation of the rectus sheath among Kenyans shows some variations which have not been reported by previous workers. Knowledge of these variations is important in surgery as this sheath is always incised when making most aabdominal incisions.

KEY WORDS: Rectus sheath ; Kenyans ; Anterior abdominal wall.

\section{INTRODUCTION}

The rectus sheath is a tendinous sheath formed by the aponeuroses of three anterolateral abdominal muscles: external oblique abdominis (EOA), internal oblique abdominis (IOA) and transversus abdominis (TA) (William et al., 1998). This sheath has two walls, anterior and posterior, that enclose rectus abdominis muscle and its neurovascular bundle. The functions of this sheath correspond to those of the muscles that form it which include generation and distribution of intra-abdominal forces (Hodges \& Gandevia, 2000), passive respiration, postural adjustments and truncal movements (Urquart et al., 2005a,b).

Usually the anterior wall is made up of the aponeuroses of EOA and IOA above the arcuate and aponeuroses of all the three anterolateral abdominal muscles below this line (Williams et al.). According to these authors, the posterior wall only extends to the arcuate line and is made up of the aponeuroses of IOA and TA. Variations in this pattern of formation of the rectus sheath have been observed.
In a study by Monkhouse \& Khalique (1986), the aponeurosis of IOA above the arcuate line of Douglas split into two laminae that enclosed the rectus abdominis (RA) muscle in up to $60 \%$ of the cases, while in $27.5 \%$ of the cases both laminae passed anterior to the RA. In the same study, TA split to enclose the RA in $12.5 \%$ of the cases. It is however not clear whether these variations are population specific. This study therefore aimed at describing the pattern of formation of the rectus sheath in a select Kenyan population.

\section{MATERIAL AND METHOD}

The rectus sheaths were obtained from eighty subjects aged 18 to 70 years. Of these, 31 (16 male, 15 female) were collected from the Nairobi's City and Chiromo Mortuaries during autopsies. The remaining 49 (31 male, 18 female)

* BSc Anat, MBChB, Department of Human Anatomy, University of Nairobi, Kenya.

** BSc Anat, MBChB, MMed (Surg), Department of Human Anatomy, University of Nairobi, Kenya.

*** MBChB, MMed (Surg), Dip (SICOT), Department of Human Anatomy, University of Nairobi, Kenya.

${ }^{* * * *}$ MBChB, MMed (Surg), Department of Human Anatomy, University of Nairobi, Kenya. 
were acquired from cadavers used for routine dissection by first year medical students at the Department of Human Anatomy, University of Nairobi.

The rectus sheath was exposed through a midline skin incision followed by dissection and clearance of the superficial fascia. Another incision was made through the rectus sheath midway between the umbilicus and the costal margin. The caudal segment was then reflected laterally so as to view the posterior wall of the rectus sheath, which was then dissected laterally with the help of a dissecting lens so as to visualize its pattern of formation. Photographs illustrating the pattern of formation of the rectus sheath were taken using a Fujiß digital camera (Finepix A900, 9 megapixels).

\section{RESULTS}

Anterior wall of the rectus sheath (AWRS). All the cases, the anterior wall of the rectus sheath was aponeurotic and firmly attached to the rectus abdominis muscle (Fig. 1A). These attachments were however strongest at the tendinous intersections of RA. Above the costal margin, the anterior wall of the rectus sheath was solely formed by the aponeurosis of external oblique abdominis muscle. Below the costal margin, the internal oblique abdominis muscle in all the cases split into two laminae: a superficial and a deep one (Fig. 1A). The superficial lamina fused with the aponeurosis of the external oblique abdominis mid-way between the medial and lateral borders of rectus abdominis muscle. When the arcuate line was present (64 cases), all the anterolateral abdominal wall muscles passed anterior to rectus abdominis muscle to form the AWRS (Fig. 1B).

Posterior wall of the rectus sheath (PWRS). PWRS was made up of the aponeuroses of TA and the deep lamina of IOA. Fusion of the TA with the deep lamina of IOA was at the lateral border of RA muscle (Fig. 1A). This wall was aponeurotic in $71(88.5 \%)$ cases, the rest were musculoaponeurotic. The musculoaponeurotic posterior walls of the rectus sheath were found in males only. In these cases, the muscle fibres were derived from transversus abdominis muscle and their content decreased caudally such that below the umbilicus the posterior wall of the rectus sheath was purely aponeurotic (Figs. 1C and 1D).

\section{DISCUSSION}

Observations of the present study have revealed that the pattern of formation of the rectus sheath is different in three regions namely; above the costal margin, between the costal margin and the arcuate line and below the arcuate line. In this study, the aponeurosis of internal oblique abdominis muscle between the costal margin and the arcuate line split to enclose the rectus abdominis muscle in all cases. This is consistent with the findings by Rizk (1980) but differ with those by Monkhouse et al. who observed three different patterns of formation of this sheath. In the study by the latter workers, only $60 \%$ of the cases conformed to the pattern in the present study. In $27.5 \%$ of the cases, the internal oblique abdominis did not split but passed anterior to the rectus abdominis leaving the transversus abdominis to form the posterior wall of the rectus sheath. In the same study, transversus abdominis split to enclose the rectus abdominis in $12.5 \%$ of the cases.

The pattern of formation of the rectus sheath may be explained by its embryogenesis (Walmsley, 1937; Skandalakis et al., 1997). The anterior abdominal wall is first formed by ectoderm and parietal mesoderm which form somatopleura (Skandalakis et al.). According to these workers, the ventral abdominal wall muscles are derived from the lower thoracic myotomes that migrate ventrally invading the somatopleura during the sixth week of intrauterine life. Rectus abdominis muscle develops first from the tips of these myotomes then the rest of the mesodermal sheet divides into two strata: internal oblique stratum and external oblique stratum (Walmsley). The internal oblique stratum gives rise to transversus abdominis and internal oblique abdominis muscles while the external oblique stratum develops into external oblique abdominis muscle (Walmsley). Later in development, the distal parts of the muscles become aponeurotic (Rizk \& Adieb, 1982). The aponeurosis of the internal oblique abdominis muscle attaches to the primordial rectus sheath and grows on both anterior and posterior surfaces towards the linea alba forming its superficial and deep lamina (Walmsley). External oblique becomes placed anterior to the superficial lamina of internal oblique because it is derived from the external oblique stratum that lies ventral to the internal oblique stratum (Rizk \& Adieb). Transversus abdominis muscle on the other hand assumes a position posterior to the deep lamina of internal oblique as it is derived from the internal oblique stratum (Skandalakis et al.).

The morphology of the adult rectus sheath cannot be fully explained by its embryology. As observed in the present study and by other workers, AWRS is firmly attached to RA while the PWRS is not (Williams et al.; Sinnatamby, 2000). The maturation of the rectus sheath could be influenced by the mechanical activities of the muscles of the anterior abdominal wall. The upper fascicles of transversus abdominis act as a circular compressor of 


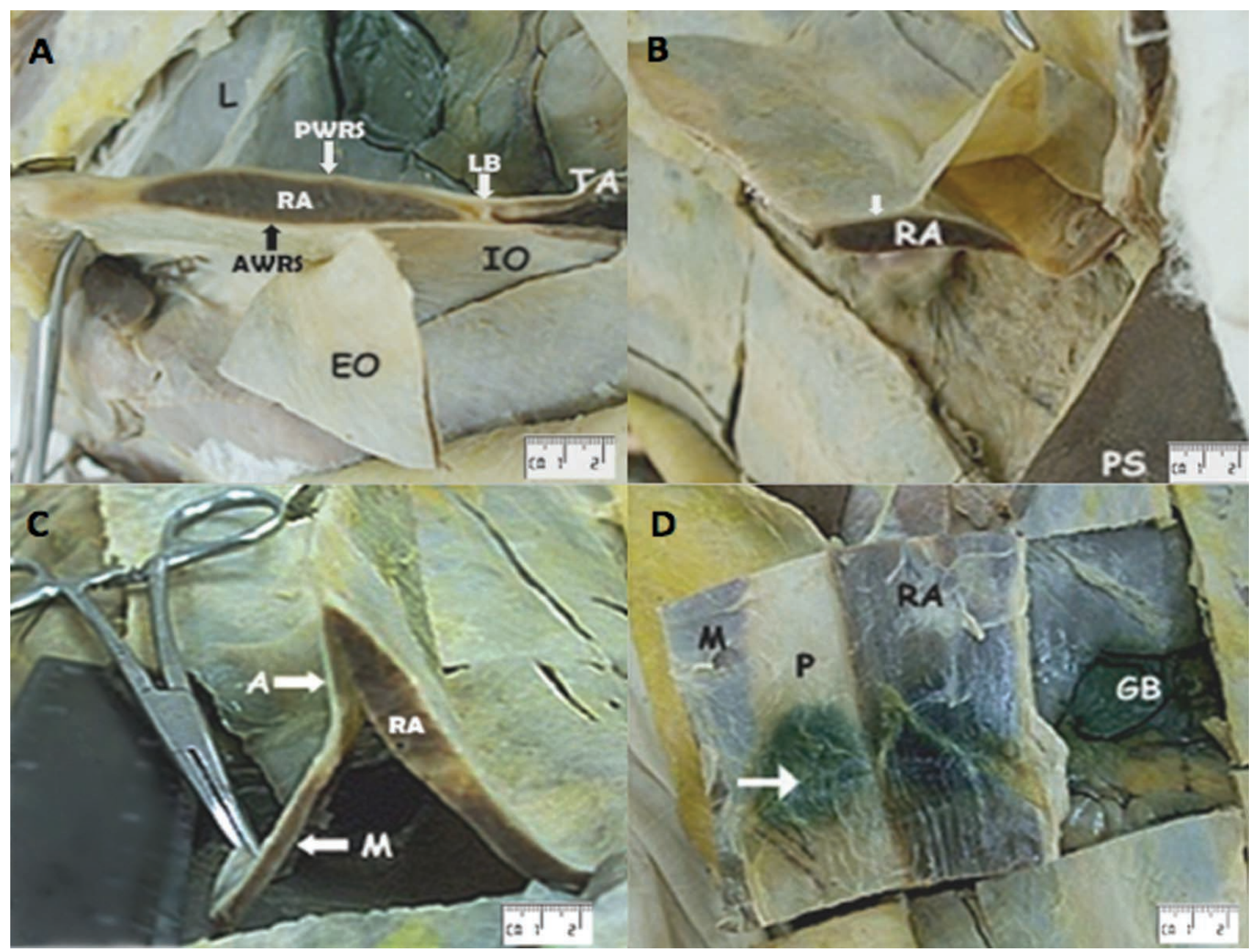

Fig. 1. A transverse section of the rectus sheath and its contents. A: Below the costal margin. Note that internal oblique (IO) split to enclose the rectus abdominis muscle (RA). Its superficial lamina fuses with external oblique (EO) near the middle of the RA while the deep lamina fuses with transverses abdominis (TA) at the lateral border (LB) of RA. B: Below the arcuate line. Note that the posterior wall is deficient at this level. The arrow points at the anterior wall of the rectus sheath. RA, rectus abdominis; PS, pubic symphysis. C: A transverse section through the rectus sheath showing a musculoaponeurotic PWRS. Note the medial part is aponeurotic (A) while the lateral part is muscular (M). D: Diagram showing a musculoaponeurotic type of PWRS (arrow). Rectus abdominis (RA) muscle has been reflected laterally. M, muscular part; P, aponeurotic part; GB, gall bladder.

both thoracic and abdominal cavities (Hodges \& Gandevia). Their location deep to the rectus abdominis coupled by the fact that the PWRS is not firmly attached to the RA may be a biomechanical adaptation. As evidenced by physiological studies, these fascicles of TA are recruited before other muscles of anterior abdominal wall during truncal flexion and respiration (Hodges et al., 1997; Urquart et al., 2005b). Contraction of TA therefore increases the separation between the PWRS and the RA. This may facilitate smooth gliding of the rectus abdominis muscle.

As seen in the present study and in other studies (Rizk, 1991; Monkhouse \& Khalique), the aponeuroses of transversus abdominis and internal oblique abdominis below the arcuate line blended with that of external oblique abdominis muscle to form the anterior wall of the rectus sheath. The lower fascicles of TA and IOA support abdominal viscera and generate forces that compress the sacroiliac joints for postural stability (Richardson et al., 2002). Electromyographic studies on the TA have shown greater tonic activity in the lower fibres during upper limb movements (Hodges et al., 1999). Rapid flexion of the upper limb produces a brief challenge to postural stability of the trunk with most of the effects being felt at the sacroiliac joints (Bouisset \& Zattara, 1987). Contraction of lower fibres of TA and IOA flexes the spine leading to stabilization of the sacroiliac joints (Richardson et al.). The rectus abdominis is also recruited during these maneuvers (Hodges 
et al., 1997). The anterior position of these aponeuroses is thus the most favorable as the fibres act on the most curved surface with the contracted RA acting as a rigid support.

The posterior wall of the rectus sheath in the current study was aponeurotic in $88.5 \%$ of the cases, the rest were musculoaponeurotic. This is at variance with the findings by Monkhouse \& Khalique, who found aponeurotic sheaths in $42.5 \%$ of the cases, the rest were muscular. The dissimilarity in the findings could be as a result of the methods used. Monkhouse \& Khalique were not clear on their definition of muscular sheaths. In the present study however, the posterior wall of the rectus sheath was not entirely muscular but musculoaponeurotic with the muscular content decreasing caudally towards the arcuate line. This observation may be an adaptation of the transversus abdominis muscle in generating intra-abdominal pressure. Pertinent to this is the report by Muramatsu et al. (2001) that skeletal muscles contain contractile elements (muscle fibres) and elastic components (aponeuroses or tendons). The elastic component interacts with the contractile element (Kubo et al., 2000) and functions as a store of elastic energy when the muscle contracts (Alexander, 1984). It is plausible therefore that the aponeurotic part of transversus abdominis stores energy when this muscle contracts and releases the energy when the muscle relaxes. This leads to build up of pressure in the lower abdomen.
The musculoaponeurotic PWRS were found only in male individuals. This could be as a result of hormonal influence. In general, males contain more muscular tissue than females (Komi \& Karlsson, 1978, Griggs et al., 1989). These workers attributed the increase in muscle to the more pronounced contractile elements and metabolic enzymes in males as a result of testosterone.

\section{CONCLUSION}

The pattern of formation of the human rectus sheath among Kenyans shows variations which are different from those reported by previous workers. Knowledge of the variations in the pattern of formation of the human rectus sheath is important in surgery as it is incised in most abdominal incisions, and may complicate with incisional hernias if the sheath is not properly sutured.

\section{ACKNOWLEDGEMENTS}

We are especially thankful to Dr. Julius Ogeng'o, Dr. Hassan Saidi and other teaching staff at the Department of Human Anatomy, University of Nairobi, for extending their valuable support in completing this study.

MWACHAKA, P.; ODULA, P.; AWORI, K. \& KAISHA, W. Variaciones en el patrón de formación de la vaina del músculo recto abdominal en kenianos. Int. J. Morphol., 27(4):1025-1029, 2009.

RESUMEN: El patrón de formación de la vaina del músculo recto abdominal humano muestra variaciones, no está claro si estas variaciones son población-específicas. Este estudio tiene como objetivo describir el patrón de formación de la vaina del músculo recto del abdomen en una población seleccionada de Kenia. La formación de la vaina del músculo recto del abdomen se analizó en 80 sujetos (47 hombres, 33 mujeres) durante autopsias y disección de cadáveres. La pared anterior de la vaina del músculo recto en todos los casos era aponeurótica y firmemente unida al músculo recto abdominal. La pared posterior de la vaina del músculo recto era aponeurótica en 71 $(88,5 \%)$ casos, las paredes restantes eran musculoaponeuróticas y sólo se observaron en varones. En todos los casos, la aponeurosis del músculo oblicuo interno del abdomen se dividió en dos láminas, una lámina profunda que se fusionaba con la aponeurosis del músculo transverso del abdomen en el borde lateral del músculo recto del abdomen y una lámina superficial que se fusionaba con la aponeurosis del músculo oblicuo externo del abdomen a mitad del recorrido entre los bordes medial y lateral del músculo recto del abdomen. El patrón de formación de la vaina del músculo recto del abdomen, entre los kenianos muestra algunas variaciones que no han sido reportadas en trabajos anteriores. El conocimiento de estas variaciones es importante en cirugía ya que esta vaina es seccionada en abordajes abdominales.

PALABRASCLAVE: Vaina del músculo recto del abdomen; Kenianos; Pared abdominal anterior.

\section{REFERENCES}

Alexander, S. Physiologic and biochemical effects of exercise. Clin. Biochem., 17(2):126-31, 1984.

Bouisset, S. \& Zattara, M. Biomechanical study of the programming of anticipatory postural adjustments associated with voluntary movement. J. Biomech, 20(8):735-42, 1987.
Griggs, R. C.; Kingston, W.; Jozefowicz, R. F.; Herr, B. E.; Forbes, G. \& Halliday, D. Effect of testosterone on muscle mass and muscle protein synthesis. J. Appl. Physiol., 66:498-503, 1989.

Hodges, P. W.; Cresswell, A. \& Thorstensson, A. Preparatory trunk motion accompanies rapid upper limb movements. 
Exp. Brain Res., 124:69-79, 1999.

Hodges, P. W. \& Gandevia, S. C. Changes in the intra-abdominal pressure during postural and respiratory activation of the human diaphragm. J. Appl. Physiol., 89:967-76, 2000.

Hodges, P. W.; Gandevia, S. C. \& Richardson, C. A. Contractions of specific abdominal muscles in postural tasks are affected by respiratory maneurves. J. Appl. Physiol., 83(3):753-60, 1997.

Komi, P. V. \& Karlsson, J. Skeletal muscle fibre types, enzyme activities and physical performance in young males and females. Acta Physiol. Scand., 103(2):210-8, 1978.

Kubo, K.; Kanehisa, H.; Kawakami, Y. \& Fukunaga, T. Elasticity of tendon structures of the lower limbs in sprinters. Acta Physiol. Scand., 168:327-35, 2000.

Monkhouse, W. S. \& Khalique, A. Variations in the composition of the human rectus sheath: a study of the anterior abdominal wall. J. Anat., 145:61-6, 1986.

Muramatsu, T.; Muraoka, T.; Takeshita, D.; Kawakami, Y.; Hirano, Y. \& Fukunaga, T. Mechanical properties of tendon and aponeurosis of human gastrocnemius muscle in vivo. J. Appl. Physiol., 90(5):1671-8, 2001.

Richardson, C. A.; Snijders, C. J.; Hides, J. A.; Damen, L.; Pas, M. S. \& Storm, J. The relationship between the transversus abdominis muscles, sacroiliac joint mechanics, and low back pain. Spine, 27:399-405, 2002.

Rizk, N. N. A new description of the anterior abdominal in man and animals. J. Anat., 131(3):373-85, 1980.

Rizk, N. N. The arcuate line of the rectus sheath-does it exist? J. Anat., 175:1-6, 1991.

Rizk, N. N. \& Adieb, N. The development of the anterior abdominal in the rat in the light of a new anatomical description. J. Anat., 134(2):237-42, 1982.

Sinnatamby, C. Last's anatomy, $10^{\text {th }}$ Ed. Edinburg, Churchill Livingstone, 2000. pp.218-9.

Skandalakis, J. E.; Colborn, L. \& Skandalaki, J. L. The embryology of the inguinofemoral area: An overview. Hernia, 1:45-7, 1997.

Urquart, D.; Hodges, P. \& Story, I. Postural activity of the abdominal muscles varies between regions of these muscles and between body positions. Gait \& Posture, 22:295-305, 2005a.

Urquart, D.; Parker, P.; Hodges, P.; Story, I. \& Briggs, C. Regional morphology of the transversus and obliquus internus and externus abdominis muscle. Clin. Biomechs., 20:233-41, 2005b.

Walmsley, R. The sheath of rectus abdominis. J. Anat., 71:404-14, 1937.

Williams, P. L.; Bannister, L.; Berry, M.; Collins, P.; Dyson, M.; Dussek, J. \& Fergusson, M. Gray's Anatomy. $38^{\text {th }}$ Edition. London, Churchill Livingstone, 1998. pp.5519.

Correspondence to:

Philip Maseghe Mwachaka

Department of Human Anatomy

University of Nairobi

P. O. Box $30197-00100$ GPO

Nairobi, KENYA

Telephone : +254723353913

Email : pmaseghe@gmail.com

Received : 18-02-2009

Accepted : 09-09-2009 
